\title{
Experiences of Turkish Children Learning English as a Second Language in South Africa: Collapsing Home-School Boundaries
}

\author{
Aysegul Ergul \\ Faculty of Education, University of Johannesburg, South Africa \\ Email: aysegultopuz@hotmail.com \\ Leila Kajee \\ Faculty of Education, University of Johannesburg, South Africa \\ Email: Ikajee@uj.ac.za
}

Doi:10.5901/mjss.2014.v5n10p409

\begin{abstract}
New immigrants face major challenges which affect their integration into a host country. One of their main problems is the inability to communicate in the language of the host country, as language and social practices of immigrants often differ considerably from the host country's mainstream language and values. The aim of this paper is to explore the experiences of Turkish children who are learning English as a second language in South Africa, in an attempt to help bridge the language and literacy gaps between their homes and schools. Through interviews, home visits and observations, the paper makes recommendations for more congruency between home and school literacies.
\end{abstract}

Keywords: Literacy as social practice, immigrant literacy, home-school congruence,

\section{Introduction}

Immigrants, when leaving their home countries also leave everything familiar behind: their family, friends, and support network. They do not only arrive in a country with their children and spouses, but also with their own culture and language, ready to integrate (or not), with the host culture and language. Their arrival in a new country is characterised by many uncertainties including "a pressure for a speedy and successful adjustment to a new lifestyle, effective use of a new language, and clear commitment to a new set of cultural values" (Delgado-Gaitan, 1991: 22-23). Possible racism and other exclusionary behaviour towards immigrants and their families in their new country are additional challenges, making immigration a daunting task indeed (Blackledge, 2000).

The global concept of immigration and immigrants applies to South Africa as well, a country that has a heterogeneous population base and is a very ethnically and linguistically diverse country. Although, as Landau discusses, "the regions' dynamic communities and extended, highly porous borders make it all but impossible to track across them with any accuracy" (Landau, 2006a: 225), what is clear is that South Africa has a large number of immigrants from all over the world. According to Documented Migration 2003 for instance, in 2003 the number of documented immigrants to South Africa was 10578, an increase of $61,6 \%$ as compared to the previous years (Statistics SA, 2003). This demonstrates that South Africa has an increasing number of immigrants coming here for various reasons. To illustrate, the Turkish community in South Africa is expanding daily, bringing their own language and culture to the country. Turks come to the country for several social and economic reasons including business and further study.

In the context of new immigrants, there are major challenges affecting their integration. One of their main problems is the inability to communicate in the language of the host country, as language and social practices of immigrants often differ considerably from the host country's mainstream language and values. As Degado-Gaitan argues, the transmission of the language is the foundation of problems related to the adjustment of immigrants to their new countries, as it is "the appropriate mechanism for achieving upward social mobility" (1991: 29) and "the instrument par excellence for social intercourse" (1991: 25) by linguistically different groups.

Linguistic integration is also a challenge for, in this study, new Turkish immigrants who speak only Turkish. They have to try to adjust linguistically by learning English, which is a dominant language in South Africa. This process is problematic especially for children who will continue their education in their new country, make new social groups and open new lines of communication through their school life. Hence, they are the ones who are pressurized to make a rapid adjustment to their new language. In this case it is essential for these children to learn English, which is most likely the medium of instruction in South African classrooms. 
It is often the case that Turkish children start school in South Africa before they become proficient in English and learn English in the school environment, as they speak only Turkish in their homes. Because their parents do not speak English, they cannot understand much of what goes on at school and cannot assist their children in this very important context. The situation reflects the lack of congruence between school and home literacies which is the second problem in this context. According to Blackledge, where socio-cultural congruence exists between home and school settings, children have a greater chance of academic achievement; and parents who are informed about the school's expectations and how the school runs may support their children better than those who are not (2000:7). Therefore learners will become proficient in literacy by "collapsing the boundaries between their classroom and their communities" (Pierce, 1995: 26). Thus congruence between homes and schools is certainly a strong consideration.

However, educators sometimes do not take cognizance that these children are exposed to only the mother tongue in the home, and it is most likely that their home literacies are ignored in the classroom. So, a conflict arises when immigrant children with little or no knowledge of English are taught in English medium of instruction at schools in a way that marginalizes and decontextualizes their mother tongue and culture. Blackledge elaborates on the same conflict and claims that "schools facilitate the exclusion of students and parents by (consciously or unconsciously) establishing activities that require specific culturally-based knowledge and behaviors" (2000: 7) by underestimating and ignoring their everyday lives in their homes. However, it is the school's responsibility to have respect for, and appreciation of, students' home languages and cultures and to make students' daily experiences in both home and school relevant to each other and equally supporting (Haneda, 2006: 343).

\section{Research Aims and Questions}

The aim of this paper is to explore the experiences of Turkish children who are learning English as a second language in South Africa, in an attempt to help bridge the language and literacy gaps between the homes of the immigrant children and the school in relation to their literacy practices. Thus the paper attempts to answer the following questions: What are the experiences of Turkish children who are learning English as a second language in South Africa, and what is the relationship between the home language and the language used in school?

\section{Research Context}

The private Muslim school at which this research was conducted is located in Mayfair, Gauteng, South Africa. Although it is a Muslim school, it has teachers and learners from other religious groups as well. Although the school was established and run by a Turkish Education Trust, it follows the South African School curriculum, and the medium of instruction is English. The teachers, like the learners, are quite diverse. There are teachers from Turkey, Kenya, Azerbaijan and Algeria, as well as South African teachers. Turkish immigrants tend to prefer this school for their children because of the large number of Turks at the school. .

\section{Literature Review}

In order to provide a deeper understanding of the data collected as well as provide a framework for data analysis, this research is located within the "literacy as social practice" framework (Gee, 1996; Street, 1998; Barton, Hamilton and Ivanic, 2000), since the literacy practices of Turkish immigrant children observed are included within their general social practices. In this regard, this paper provides various definitions of literacy. Based on these definitions, it provides literature about how literacy cannot be considered as having a singular form in the context of Turkish immigrant children who are learning a new form of literacy in their social settings - school, home, community and immigrant literacies; it is multiple and dynamic, changing according to different languages and cultural settings.

\subsection{What is Literacy?}

Literacy traditionally means the ability to read and write. This definition of literacy is variously depicted as 'mainstream' by Heath (1983), 'schooled' by Street and Street (1995) or 'official' by Dyson (1997). However, it is very difficult to find a single and definite definition for 'literacy'. Theorists, such as Street (1998) and Blackledge (2000), started to question whether literacy is the same for everyone or there can be co-existent literacies; whether literacy can be learnt only at school or it is also learnt in students' homes and communities, what role the literacy plays in societies where there are unequal relations of power between different groups (in the case of this project, immigrant families). Thus theorists, such 
as Street (1998), Gee (1996), Heath (1983), started to take a sociocultural perspective of literacy, "challenging approaches which emphasize decontextualized basic skills" (Stephens, 2000: 10).

\subsubsection{Literacy as social practice}

The notion of literacy as social practice is shared by Street (1998) and Barton, Hamilton and Ivanič (2000). The concept of literacy as social practice sees literacy not only as a set of technical skills to be learnt at formal education institutions but as social practices that come about in everyday lives of people and vary according to cultural and social contexts in which they are situated. Similarly, according to Street, literacy happens "naturally in social life, taking account of the context and their different meanings for different cultural groups" (2003: 79). Since we cannot diminish social practices to only one action to be learnt, literacy also cannot have only one form; and it changes according to social and cultural contexts in which people find themselves. Therefore, the concept of literacy as social practice displays a move from literacy being an individual quality to probing ways in which people in groups and communities use literacy. In other words, literacy practices are parts of larger social activities.

\subsubsection{Immigrant literacies}

When reflecting on the literacy practices of immigrant children, the idea of literacy as social practice is significant, because they unavoidably have to take part in a variety of literacy practices in different languages and in different domains. Seen from an educational point of view, the literacy of the school has come to be seen as the dominant literacy; yet, it is essential to acknowledge that there are many different literacy practices in individuals' lives which are distinctive from the school literacy.

In this case, the studies of Delgado-Gaitan and Trueba (1991) and Blackledge (2000) are crucial to the literature on immigrant literacies in this paper. The researchers cited study immigrant children's schooling in the host country and the difference between their home and school literacies. Blackledge's (2000) study focuses primarily on immigrant Bangladeshi families in Birmingham. His study reveals that, although the children's teachers view parents who cannot read or write English as illiterate, these children have real power in their homes and communities and their parents eagerly help their children's literacy in the home language. Similarly, Delgado-Gaitan (1991) studies children of Mexican and Central American families in the Secoya Community in United States. Her findings expose that the families' rich cultural and linguistic practices are the main tool for their literacy empowerment.

Blackledge (2000), Delgado-Gaitan \& Trueba (1991) and Delgado-Gaitan (1991 therefore, make a vibrant link between the notion of literacy as social practice and immigrant literacies by considering literacy in terms of "culturally meaningful literacy interactions (for example, family members listening to children read), and in the context of relations of power between majority and minority groups in society" (Blackledge, 2000: 2). Hence, literacy has different connotations in the homes of immigrant children and local children, and in the homes of immigrant children and in school (Blackledge, 2000: 3).

\subsubsection{Literacy practices in immigrant homes}

In this concept of different meanings of literacy for culturally and linguistically different groups (immigrants, in this project), different home literacy practices have been seen as a primary factor in a child's success or failure in school literacy (Gregory and Williams, 2000: 158). Until recently it was mostly believed that minority-culture and language children do not have any effective support at home for their language and literacy learning, and the reason for their underachievement was assumed to be their or their families' lack of literacy skills or lack of proficiency in the dominant language (Blackledge, 2000; 4). However, recent research addressing immigrant minority language children emphasizes the importance of an understanding that literacy development cannot be confined to school boundaries and is intimately associated with the out-of-school literacy practices (Delgado-Gaitan, 1994; Valdez, 1996; Gregory and Williams, 2000; Moll, 2002; Gillanders\& Jimenez, 2004). Authors such as Blackledge (2000) and Delgado-Gaitan (1994) have observed and tried to understand the literacy practices that children from culturally and linguistically different backgrounds have in their homes and communities. Gregory and Williams also aimed to uncover some ways in which "children syncretise or blend home, community and school language and learning styles to enhance both home learning and official school achievement" (2000: xviii). The findings of these studies display that these groups having traditionally been considered to be lacking in literacy skills often have rich linguistic surroundings in their homes and offer a variety of literacy practices to their children. 
In this regard, because literacy does not only imply universal technical skills to be learnt, "it is important that schools and policy-makers identify the social functions, meanings, and values attached to literacy in particular communities" (Blackledge, 2000: 5) in order to provide equal opportunities for children who are learning literacy. It is, moreover, recommended that the culture and history of linguistically and culturally different children's communities must be learnt from a critical perspective, and children's developing literacy and language must be considered and cherished as surrounded in these contexts (Gregory, Long and Volk, 2004: 223).

\subsubsection{School literacy practices}

Literacy practices of the schools and the meaning that the school gives to literacy may differ from those of the communities they serve. If the use of literacy is similar at school and in the home and the cultural background of the children is consistent with what the school values, this is less likely. According to Blackledge 2000: 6), authority is vested in those belonging to the mainstream culture, therefore the literacy practices of the mainstream become norm and have higher status in the school context. Consequently, it is obvious that this standardized literacy instruction at school is unable to see the differences between the understanding of literacy valued at school and literacy practices in the homes of linguistically and culturally different children.

What Blackledge (2000) argues about the literacy of school is consistent with the previously discussed ideological model of literacy of Street (2003) which claims not only that literacy is embedded in different cultures and communities, but also that it is fabricated by power relations in society. School is one such institution which has a tendency to support dominant literacy practices, and thus, as Kajee argues, the teaching of one type of literacy could privilege certain groups, while disempowering others, such as immigrant children who have not had extensive access to that dominant literacy (2011).

\subsubsection{The congruence or lack of congruence between home and school literacies}

In the former sections, it was argued that immigrant children have literacy practices that differ between the home and school, rooting the assumption that the meaning attached to literacy may vary in different cultural and linguistic contexts. This may cause a discrepancy when these children who have little or no competence in the English language are taught the entire school curriculum in English in a way that their home language and culture are invalidated or marginalised. So, certain scholars, such as Haneda (2006), question the reasons for some children's tendency to be alienated when it comes to school literacy practices, although they have remarkably active literate lives outside school.

Some theorists believe that the main answer for such questions as posited by Haneda (2006) is the idea that these linguistic and cultural differences in the home and in the school are seen superficially "as obstacles to concept development, rather than as resources or bridges to facilitate children's transitions from their home culture and language to the culture and language of the school" (Delgado-Gaitan, 1991: 38). Thus, despite the fact that these children lead lives outside the school which is full of meaningful literacy activities with their families such as story reading (Gregory and Williams, 2000), religious activities (Kajee, 2011) or recipes (Da Silva Iddings, 2009), schools and teachers are unable to realize this, as well as cultural conflicts in minority populations caused by this lack of congruence (Delgado-Gaitan, 1991: 24).

That is when the boundaries between homes and schools of immigrant children are blurred or crossed, so that the teachers have a chance to see the child as a whole person who can be actively involved in multiple spheres of literacy and knowledge, and students' investment in school learning increases. Moreover, if schools value the home learning settings of children, Delgado-Gaitan thinks, "parents of ethnic and linguistically different children can become a strong support for academic learning, and can help smooth the transition of children from one cultural environment to the other" (1991: 31). Therefore, educators should rethink how they define being literate in order to give the learners access to a wide range of literacy practices, which would help them create futures in a rewarding and responsible manner (Haneda, 2006: 343).

\section{Research Design and Methodology}

This research is a qualitative case study, the aim of which is to examine the experiences of Turkish speakers who are learning English in South Africa. The project involves field research which involves observation of "real life events" (Knobel and Lankshear, 1999: 84) and where the focus is on "the kind of evidence 'what people tell you, what they do' that will enable you to understand the meaning of what is going on" (Gillham, 2000: 10). This research is, consequently, a 
qualitative case study using data collection methods such as interviews and classroom observations which allow an exploration of interesting data in order to be able to interpret and find answers to my research questions.

Based on definitions by Yin (1994), Knobel and Lankshear (1999) and Gillham, (2000), a case study is an in-depth, descriptive and interpretive study that focuses on a single bounded instance. It is based on real-life contexts, and relies on multiple sources of data collection. Thus, this research is in the form of a case study with "identifiable boundaries" (Henning, 2004: 41) grounded on the context of Sky Primary and High School ${ }^{1}$ in central Johannesburg, as it is mentioned in the research context section, with the participants being a sample Turkish immigrant students who are learning English in their school environment, as well as some of their teachers and parents.

\subsection{Research site}

Although the school was established and run by a Turkish Education Trust, it follows the South African School curriculum, and the medium of instruction is English. As soon as one enters the school, one can sense the diversity in the air. There are children from many different backgrounds playing in the school yard in their blue and navy uniforms. The mosque next to the school gate gives an idea of the learners' religious profile; the learners are predominantly Muslims. On the other side of the gate is the sports court for the learners' sports activities. There is also a grass playground at the back of the school, where the children can play sports and run freely. The school section has 55 educators, with 366 learners in the primary section (Grade R to Grade 7) and 240 learners in high school. Having primary and high school learners in the same school may cause some problems such as sharing the same playground during the break time or shortage of playing areas for the sports activities.

\subsection{Research participants}

Purposive sampling was used to discern, comprehend and gain insight; in other words a sample was selected so that the most could be learnt (Merriam, 1988, 2002). Although the school has many immigrants, it was decided to focus on Turkish immigrant children, as one researcher knew them and their families personally, and is herself a Turkish immigrant. Among all Turkish immigrant children at the school, three of them were chosen as the focus of the project due to the fact that two of them (Sevda and Mehmet ${ }^{2}$ ) immigrated to South Africa recently and are still in the process of acquiring English and school literacy. The other, Ayse came to South Africa five years ago, however she qualified as a participants due to her still having adaptation and language problems, despite being in South Africa for five years.

All three children are in Grade 7, so they have the same school subjects and the same teachers for each subject, and they are almost at the same age as it is indicated in the table below. This was an advantage for us as they are undergoing the same experiences in terms of adapting to a new environment and learning a new language. In my sample of children two are female and one is male. They all speak Turkish as their home language and learning English as a second language in the South African school context. Mehmet is a 12-year old male who came to South Africa in July 2009. Ayse is a 14-year old female who came to the country in July 2006, and Sevda is a 13-year old female whio entered the country in December 2008.

In addition to Turkish immigrant learners, their parents and some of their teachers were participants in the study. The interviews could only be conducted with the mothers of the learners because their fathers were busy at the time, and they spent more time at home with their mothers than their fathers. Despite having three learner participants, only two of the parents participated in the research because of the poor health of the third parent. Aynur, Mehment's mother is a Biology teacher, and Rumeysa, Ayse's mother is a housewife.

The last stakeholder of the study is a sample of teachers at Sky Primary and High School. Three teachers, who were selected as participants, teach different subject areas and have different levels of experience. What is common for all teacher participants is their teaching to Grade 7 learners. Mrs Khan is a 25-year old English teacher with 5 years teaching experience. Mrs Karodia is a 45-year old female who has been teaching Islamic Studies for 25 years, and Mrs Adams, who is 52 years old has been teaching Afrikaans and Social Studies for 25 years.

\subsection{Data collection}

Data was collected through interviews and observations. Interviewing is a valuable source to access the participants'

\footnotetext{
${ }^{1}$ The name of the school has been changed to maintain the privacy for ethical reasons.

${ }^{2}$ Pseudonyms are used for participants for ethical reasons.
} 
views. The main purpose of an interview, according to Henning, is "to bring to our attention what individuals think, feel and do and what they have to say" (2004: 52) about their experiences and opinions. In this regard, both focus group interviews and individual interviews were conducted. Focus group interviews are beneficial to encourage debate and discussion among the participants, while individual interviews give the participants more privacy and freedom to express what they really think. There are three main stakeholders in the individual interviewing process which are children, their parents and teachers. Although teachers and parents were interviewed only individually, a focus group interview with the children was conducted.

The interviews were voice recorded and complemented by extensive written notes. After collecting the above data the audio recordings of the conversations were transcribed. The use of transcripts are helpful when analysing the data collected, as it is very difficult to do so by merely listening to what people say about their experiences.

One other important issue with regard to transcribing the interviews was translation. The interviews with the immigrant children and parents were conducted in Turkish, thinking that they could express themselves better in their home language, as they are not yet proficient in the English language. Hence, the primary researcher, as a native Turkish speaker, transcribed and translated those interviews into English at the same time. The main shortcoming of translating the transcripts was possible loss of exact meaning of what Turkish participants meant in the interviews. The reason for this was some Turkish words which do not have precise translation in English.

The second component in data collection is observations which are simply watching people's actions, listening to their conversations and asking them clarifying questions at times (Gillham, 2000: 45) in both the homes and the school of the immigrant children. The children were observed in the classroom and in their homes in order to observe their interaction with their teachers and peers, as well as their home literacies and literacy activities in which they participate with their families. During these observations, comprehensive field notes were taken (Gillham, 2000), and they form the basis of the data analysis. I noted the forms of literacy practices with their families in their homes and made detailed notes of the students' interaction as well as significant moments in the play ground and in the classroom.

\subsection{Analysis of data}

For this particular project, content analysis is used to analyse the written documents, such as transcripts of interviews and field notes, in order to "convert raw data to final patterns of meaning" (Henning, 2004: 100).

\subsection{Ethical considerations}

Throughout the research, the privacy and sensitivity of the participants as well as their teachers and family members who are involved in the study is protected. They were all fully informed about the researchers' identity and background, as well as the purpose and procedures of the research.

\section{The Experiences of Turkish Immigrant Children Who are Learning English in South Africa}

The data analysis examines the various experiences of Turkish immigrant children who are learning English in the South African school context. So, the experiences with regard to language as a communication barrier, the relationship between home language and the language used in the school, segregation between immigrant children and some local children are discussed.

\subsection{Feelings of Turkish immigrant children before coming to South Africa: "I was excited but also nervous"}

Recognising Turkish immigrant children's feelings about South Africa before coming to the country is important in this project to get an insight into their adaptation process to their new language and culture in their new country, South Africa. Research has shown that learning is destined by a sociocultural structure and further influenced by gender, socioeconomic and language differences (Grant and Sleeter, 1986; Ortiz, 1988; Rumberger, 1989). Likewise, as it is understood from the interviews that were conducted by children and parents, the nature of children's feelings about the host country before coming has a remarkable effect on their adjustment to their new environment. It was obvious that the children who had a negative image of South Africa before coming experienced a more difficult and problematic course of adaptation to both the language and the culture of the country; while the children who were equipped with necessary and correct information about the country by the parents and had a more positive attitude to the change of the culture and language were more excited about the new country and had a smoother transition from the home culture to the one of the host country. 


\subsection{Feelings about the new culture and the language: "I was scared at first"}

Of all three children, Sevda had the most difficult process of adaptation to South Africa. She said:

When my family told me about Africa, I was scared at first... I don't know... I was thinking that there were only Bushmen in Africa and there were lots of lions and other wild animals around. I was scared as I thought we would be living in small huts or shacks. My father showed me a documentary about South Africa, and I was more scared when I saw African people dance.

Sevda was scared of the unknown culture and practices in the host country. Even though her family tried to prepare her for the culture and the people of the host country by means of documentaries, she found the practices of the people of the unknown country strange and scary. The reason for her being scared of the unknown may be that she saw the country as an underdeveloped place. Her mother, Rumeysa, said:

She used to cry a lot. She wanted to go back; she didn't want to learn English. She was saying that she didn't like her friends here. I had this problem for six months. Then she started to improve slowly (Rumeysa).

It is clear that she had difficult times with Sevda after they came to South Africa and the reason why it was challenging for her to get used to the country may be her negative image of South Africa before coming here. Furthermore, leaving her friends behind in the home country caused her to overreact and reject the new culture as well as learning the English language after coming to South Africa.

Compared to Sevda, Mehmet and Ayse had a smoother adaptation process. Ayse thought that people would belong to the same culture and race as she did, and she was not aware of the fact that she was going a country with different cultural practices and language. The reason for that could be the fact that she came here at the age of 9 , and she was not old enough to recognise the meaning of a country different from home. Whereas, Mehmet, who came to South Africa at the age of 12, was very enthusiastic about new places, people and sports.

I knew it was a beautiful country. I saw some of the pictures of South Africa. I also expected a nice school. What else? I thought everything is cheap here. ..hmm..I thought I would be able to walk outside as in Turkey. I thought I would invite my friends to my home, my foreign friends, and play with them. I thought I would learn new, different sports.

Mehmet also counted himself lucky as his family encouraged him to attend a language school to familiarise him with the language of the host country. His mother said that the children in their neighbourhood knocked on their door to ask Mehmet to play soccer with them one week after they came to South Africa, and Mehmet managed to communicate with them with his broken English. This indicates that Mehmet's adaptation to his new environment and people around them was easy compared to Sevda, and he was eager to know more about the new language and culture of the people of the host country. The reason for this, I think, is that he was familiar with the culture and language before he left his home country. Therefore, as Delgado-Gaitan (1991:37) argues, the easy adjustment of immigrant and other ethnically or linguistically different children is acutely related to the quality of the learning environment in which they nurture and the type of information they were provided about the new culture.

\subsection{Language as a problem for a newcomer: "I felt like I was inferior"}

In the previous section some of the feelings and preconceptions of the Turkish immigrant children about the host country before leaving their home country were discussed; and it was argued that their image of South Africa before coming to the country influences their adaptation to it. With regard to being immigrants in South Africa, all three participant children and their parents specified in the interviews that language was the main problem after they came to the country.

Delgado-Gaitan argues that the transmission of the language is the foundation of problems related to the adjustment of immigrants to their new countries, as it is "the instrument par excellence for social intercourse" (1991: 25) by linguistically different groups. The situation was the same for Turkish immigrant children in South Africa, since the lack of English language was an obstacle to their communication with the broader community and making new friends from the culture of the host country. For all three children, not being able to speak the dominant language was a communication barrier due to the fact that they could not express themselves well and did not understand others properly. Mehmet and Ayse, for example, thought that being able to speak English was necessary to make new friends in their new country, and language deficiency was an obstacle for them to making local friends when they first came to South Africa. Ayse stated that she could not make friends easily as she could not understand what they were saying to her. Similarly, Mehmet could not join his local friends at first because of his language problem that.

Immigrant children's situation of not being able to speak the language everyone else speaks and join the local children demotivated them. For instance, Mehmet, who was very excited about both the new culture and learning a new language, felt inferior and different to the other children at school since he could not speak the dominant language as they did. Mehmet said: "I felt like I was inferior; then I had to be with my Turkish friends". 
So, as a result of the language barrier which prevented them from engaging with the children in the dominant culture, as well as the feelings aroused by not being able to speak the dominant language, they preferred to be with the children who come from the same cultural and linguistic background as they do. Additionally, Sevda avoided talking to the local children, since she thought they did not understand each other. This corresponds to observations in the playground which reveal that newly-arrived Turkish immigrant children prefer to stay in their group of Turkish friends most of the time. Similarly, Ms Adams, the Afrikaans teacher, thought that the children felt more comfortable to stay in a group of friends speaking the same language and having the same culture, as there is less to explain, and it is easier to understand.

\subsection{Turkish immigrant children's learning language through mediation: "I teach them Turkish... and they help me with English"}

The Vygotskian notion of learning language through interaction with more able adults and peers, as well as reciprocal teaching and learning (Vygotsky, 1987; Blackledge, 2000; Lantolf, 1994) were clearly recognised in all interviews with children, parents and teachers. The most prominent way of mediation in language learning in the case of Turkish immigrant children in Sky Primary School is peer mediation. Ayse and Sevda felt that their Turkish friends helped them learn English and acclimatise to the school environment more easily. The reason for this may be the fact that, as stated earlier, Sevda's unwillingness to talk to local children because of her language problem and her tendency to stay in her group of Turkish friends. So, "peers who speak the same language also act as skilled facilitators of classroom learning as they participate together in collaborative learning" (Tharp and Gallimore, 1989; Chen and Gregory, 2004). On the other hand, Mehmet was the only Turk in the class; and this, according to him, was very helpful for him to learn both the language and the culture of the local people. He said "I was the only Turk in my class. So I had to speak in English all the time, which made it easier for me to be among them". He also used other forms of peer mediation in order to learn English more quickly and make more friends from dominant culture, where he taught South African friends Turkish and they taught him English. Mediation by children from the language and culture of the host country was more helpful for Mehmet, as his learning "takes place first on an interpersonal level between participants before it is internalized on an intrapersonal level within the individual self" (Chen and Gregory, 2004). Mehmet's mother, Aynur also encouraged her son to be sociable and look for opportunities to speak the dominant language, as she believed that it would facilitate the process of learning language and the culture of the host country for Mehmet.

Teachers also have faith in peer mediation in immigrant children's learning language. Ms Adams and Mrs Karodia, for example, stated that they always encouraged immigrant children to extend what they learnt in the lesson outside the classroom and to have friends who were more proficient than themselves, as the children who had this extension were more successful. Ms Khan also thought that if immigrant children spoke English all the time rather than their own language, it would help them speak the language correctly, as the local peers support them to speak accurately. However, she claimed that immigrant children's lack of socialising with local children prevented them from learning the language more quickly. Hence, Turkish immigrant children's learning language through peer mediation shows "the primacy of social interaction" in language learning and "the importance of creating an environment where the skills, concepts, and language valued in the new community were available for appropriation by the learner through multiple modes of interaction with those more 'fluent' in the discourse of the community" (Hawkins, 2004: 12).

\subsection{Home literacy practices of Turkish immigrant children: "I have never wanted them to speak English at home"}

Haneda points out, "it is important to recognize and draw on the repertoires of literacy practices that students develop outside school in order to help school-age English language learners develop literacy competencies required for success at school" (2006: 337). In this context, there are occasions in which home literacy practices and the school literacy practices of Turkish immigrant children both differ from and are similar to each other. Even though they sometimes have to engage in school literacy activities at home due to school work and helping their siblings in their school work; they prefer to maintain their own cultural activities and literacy practices at home.

Turkish immigrant children, as in the other studies regarding the home literacy practices of immigrant children, engage in collaborative literacy activities in public spaces, such as the kitchen or the living room (Volk, 1997; Volk\& De Acosta, 2011). All three participant children speak their home language, Turkish, with their families at home at all time. This was the same when the primary researcher observed the families at home, as she is also a Turkish native speaker. During observations in the homes of immigrant children, it was not unexpected that they expressed themselves more articulately in their home language, so they always used Turkish as the medium of communication among family members. 
One reason for their involvement in literacy practices in their home language in their homes may be their parents' level of English language. Ayse's and Sevda's fathers speak English well, while their mothers are not competent in the English language at all. As for Mehmet, his mother had learnt English in South Africa at a language school, but his father cannot speak the language. So, it is obvious that the fact not all family members of the children can speak English may be one of the reasons why they always chose the home language. Secondly, Mehmet's mother, Aynur, said that she always encouraged her children to speak their home language at home in order to preserve their cultural identity.

This indicates that speaking the home language all the time at home is not only because of parents' incompetence in the dominant language, but also because of their desire to conserve their cultural identity and linguistic roots even in the host country. In this case, as Kajee points out, "speaking the language reinforces their identity", and it is one of the "symbolic markers" of cultural identity (2011: 15).

The home language of Turkish immigrant children is important for them not only to communicate among family members and friends, but it is also present in every aspect of their daily lives, as the following extract from field notes demonstrates:

The magnets on the fridge are eye-catching in their kitchen. There is a chocolate cake recipe in Turkish. There is a note on the fridge about how to make five daily prayers. There are also two magnets of the Turkish flag and a picture of Blue Mosque 3 .

Parts of their daily lives, such as recipes, pictures and instructions in the home language, indicates "the wealth of literacy practices in the lives of those often considered by the educational establishment to be 'deprived' of literacy" (Gregory and Williams. 2000: 203). The Turkish flag and the picture of Blue Mosque as the fridge magnets, are other symbolic markers which demonstrates the Turkish immigrant families' efforts to preserve their cultural identities.

Another noticeable finding is that Turkish children's out-of-school literacies are not only literacy activities shared with parents, but also activities that include siblings and other Turkish friends and families. For example, Mehmet stated that he liked reading books in Turkish more than books in English. He also occasionally read story books to his little brother which he said he enjoyed very much. These story books, like most of other books in Mehmet's bookcase, were in Turkish language.

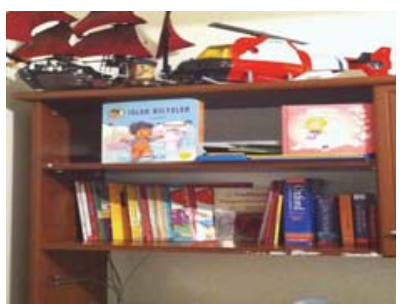

Mehmet had a variety of books in his bookcase differing in language and content. He had mostly story books for himself and his younger brother, which he said he enjoyed reading. Apart from story books, two dictionaries of English language were noticeable in the bookshelf, which he used while he studied for her school subjects. The other book is a prayer book which is in Arabic.

Unlike Mehmet, Ayse indicated in the interview that, although she tried to read English books to improve her English language competence now and then, she did not like reading even Turkish. She said she preferred watching her favourite television series 'Adini Feriha Koydum' which was, she said, a love story between a very rich boy and a poor girl studying at the same university. She downloaded each episode from the internet, or she took it from one of her Turkish friends. Furthermore, during the visit to Ayse's home, the first thing that attracted attention was the music playing on the laptop. It was a Turkish song by a very famous Turkish singer "Izzet Yildizhan".

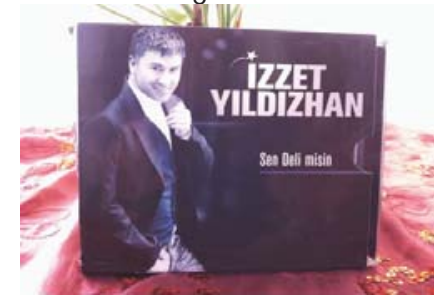

Ayse brought their collection of music CDs that her father brought from Turkey; they were all Turkish music CDs by some of the most famous Turkish singers. She even showed the researcher the songs on her laptop, predictably all the songs were Turkish. Religion also plays a vital role in all three households as a symbolic marker. Mehmet reads the Quran and

${ }^{3}$ World famous historical mosque in Istanbul, Turkey 
other prayer books on a daily basis. His mother also indicated that, although the father was very busy, they tried to have breakfast or supper together, and they usually prayed together before and after eating or performed one or two of the five daily prayers. This gave them some family time. This also demonstrates that Arabic, not just Turkish, plays a prominent role in children's homes. However, religion for children and their parents is not only about reading the Quran and prayer books. Mehmet, for example, went to a community Mosque that is frequented by Turks for Friday prayers, with his father. Likewise, Sevda mentioned in the interview that she met with Turkish friends to read and discuss religious books. These two examples indicate that the children fluctuate between home and community literacy practices. On these occasions, we experience a more "diversified use of literacy in family and community literacy practices" (Haneda, 2006; 339). Although it is sometimes claimed that the homes of immigrant or minority children have less effective literacy and language practices than the majority culture households, it is noticeable that Turkish immigrant children have many "unofficial literacies" (Gregory\& Williams, 2000: 159) in their homes which surround them with rich linguistic resources. In this regard, the consideration of children in their home-based contexts gives us the opportunity to see the child "as a whole who is actively involved in multiple spheres of knowledge and relationships" (DaSilva Iddings, 2009: 2).

\subsection{Home-school congruence}

As discussed in the previous section, children have numerous forms of out-of-school literacies varying from the books they read, the TV series they watch, the songs they listen to and the way they pray. Haneda says "it is vitally important that teachers value and build on students' existing home and community literacy practices in promoting literacy competence in school" (2006: 343). Teachers also are aware of this situation, and, according to the interviews conducted with them, they think that they understand and value immigrant children's other forms of literacy at home. Ms Khan, the English teacher, recognized immigrant children's proficiency in their home language, even though they could not communicate in the language of the school. She thought that their actual barrier was not being able to link those two languages, and it is more challenging for them not to be able to convert their vast knowledge in their home language to the language of the school. Ms Adam's view that immigrant children have different forms of literacy coincided with Ms Khan's. However, her approach to the idea was from a cultural perspective. According to her, it was easier to use children's cultural background in the class; however, the idea of extending it to the home and parents was missing. She tried to give the children from different cultural and linguistic backgrounds the chance to talk about their own culture. Moreover, she let the children present their own cultural practices in their own language in order to make the immigrant children feel a sense of belonging like the other children. One reason for her doing so was to enable the local children to realize that dominant language was not the only way to express oneself and that different people had different forms of communication that they were good at.

What these two teachers were saying during the interviews indicate that some teachers are aware of immigrant children having different forms of literacy, and they "give up the roles as gate-keepers of dominant culture and acknowledge the right of all to basic education" (Kajee, 2011: 16) by encouraging immigrant children to link those different forms of literacies for an easy adaptation and language learning. On the other hand, the main concern of some "has long been to attempt to replace the home language without any recognition of the skills and possible advantages it may bring" (Gregory and Williams, 2000: xviii).

\section{Conclusions and Recommendations}

More than an institution which is initiating a child's education, Millard claims, it is increasingly important to see the school as "building from the processes already begun within families and communities" (2005: 57). In this regard, more detailed research needs to be done in order to understand what kind of home and community literacy practices immigrant children have out of school and how the teachers can build on these practices to assist the children to link the vast existing knowledge they have in their home language and the new knowledge of the dominant language. The "unofficial literacies" (Gregory\& Williams, 2000) that children have outside the class with their parents, siblings or community members should be explored and studied elaborately so that teachers can also build on what the children have already known.

There is also need for a research on the development of systems of assistance for the construction of academic success for minority children. Effective classroom and school activities and "culturally congruent interaction" (Trueba, Jacobs and Kirton, 1990: 132) should be developed in order to help immigrant children acquire linguistic and cultural skills in the school faster and a more effective way. In this regard, Tharp and Gallimore (1989) suggest the schools to use an activity setting which provides a meaningful way to integrate culture, local context and individual function.

Not only the classroom but also the entire school can be used for educational purposes to help the children who 
are from a different linguistic and cultural background. The nature of these activities and settings, how they can be developed and implemented as well as their outcomes can be discussed in further research. Deeper research is necessary to be able to come up with different ways to facilitate minority and immigrant parents' being involved in the school, even though they do not always communicate in the language of the school and they are not always confident about going to school or speaking to teachers.

\section{References}

Barton, B. Hamilton, M and Ivanic, R. (eds) (2000). Situated Literacies: Reading and Writing in Context. London: Routeledge. Blackledge, A. (2000). Literacy, Power and Social Justices. Trentham Books Limited.

Chen, Y., Gregory, E. (2004). 'How do I read these words?' Bilingual Exchange Teaching between Cantonese-speaking Peers. In E. Gregory, S. Long, D. Volk (eds), Many Pathways to Literacy. Routledge, Falmer.

DaSilva Iddings, A.C. (2009). Bridging Home and School Literacy Practices: Empowering families of Recent Immigrant children. Theory into Practice. 48 (4), $304-311$.

Delgado- Gaitan, C., Trueba, H. (1991). Crossing Cultural Borders. The Falmer Press.

Delgado-Gaitan, C. (1991). Involving Parents in the Schools: A Process of Empowerment. American Journal of Education. 100, 20-46.

Delgado-Gaitan, C. (1994a). Sociocultural Change through Literacy: Toward Empowerment of Families. In Literacy across Languages and Cultures (143-171). State University of New York Press, Albany.

Delgado- Gaitan, C. (1994b). Consejos: The Power of Cultural Narratives. Anthropology \& Education Quarterly, 25, 298-316.

Delgado- Gaitan, C. (1994c). Russian Refugee Families: Accommodating Aspirations through Education. Anthropology \& Education Quarterly. 25, 137-155.

Dyson, A. H. (1997). Writing Super Heroes. New York: Teachers' College Press.

Gillanders, C. and Jimenez, R.T. (2004). Reaching for Success: A Close-up for Mexican Immigrant Parents in the USA who Foster Literacy Success for their Kindergarten Children. Journal of Early Childhood Literacy. 4, 243-269.

Gillham, B. (2000). Case Study Research Methods. London, NY: Continuum

Grant, C.A. and Sleeter, C.E. (1986). 'Race, Class and Gender in Education Research: An Argument for Integrative Analysis'. Review of Educational Research. 56, 195211.

Gregory, E, and Williams, A. (2000). City Literacies: Learning to Read across Generations and Cultures. Routledge.

Gregory, E., Long, S. and Volk, D. (2004). Many Pathways: Syncretic Literacy Studies for Practice and Research. In E. Gregory, S. Long and D. Volk, Many Pathways to Literacy. Routledge, Falmer.

Hawkins, M. R. (2004). Researching English Language and Literacy Development in Schools. Educational Researcher. 33 (3), 14-25.

Haneda, M. (2006). Becoming Literate in a Second Language: Connecting Home, Community and School Literacy Practices. Theory into Practice. 45 (4), 337-345.

Heath, S. B. (1983). Ways with Words: Language, Life, and Work in Communities and Classrooms. Cambridge University Press.

Heath, S. B. (1992). Oral and Literate Traditions among Black Americans Living in Poverty. In P. Shannon (ed), Becoming Political. Portsmouth, NH: Heinemann.

Henning, E. (2004). Finding Your Way in Qualitative Research. Van Schaik Publishers.

Kajee, L. (2011) "Literacy journeys: home and family literacy practices in immigrant households and their congruence with schooled literacy" South African Journal of Education. 31, 434-446.

Knobel, M and Lankshear, C. (1999). Ways of Knowing. Researching Literacy. Newtown, NSW: Primary English Teaching Association.

Landau, LB. (2006). Myth and Rationality in Southern African Responses to Migration, Displacement, and Humanitarianism. In C. Cross, G. Gelderblom, N. Roux and J. Mafukidze (eds), Views on Migration in Sub-Saharan Africa. Cape Town: HSRC Press.

Lantolf, P. L.(1994). Sociocultural Theory and Second Language Learning. The Modern Language Journal, 78, iv.

Merriam, S.B. (1988). Case Study Research in Education: A Qualitative Approach. San Francisco: Jossey-Bass.

Millard, E. (1997). Differently Literate. Boys, Girls and the Schooling of Literacy. London: Falmer Press.

Moll, L. (2002). The Concept of Educational Sovereignty. Penn GSE Perspective on Urban Education. 1(2), 1-11.

Ortiz, F.I. (1988). 'Hispanic- American Children's Experiences in Classrooms: A comparison between Hispanic and non-Hispanic children'. In L. Weis (ed), Class, Race and Gender in American Education. Albany, NY: State University Press.

Pierce, B.N. (1995). Social Identity, Investment, and Language Learning. TESOL Quarterly. 29 (1), 9- 31.

Rumberger, R. W. (1989). 'Chicano drop-outs'. In R. R. Valencia (ed), Chicano School Failure and Success: Research and Policy Agendas for the 1990's. Basing-Stoke, England: Falmer Press.

Statistics SA (2005). Documented Migration: Report No. 03-51-03 (2003). Available at http://www.statsa.gov.za/PublicationsHTML/Report-03-51-032003/htm//Report-0351-032003.html [accessed June 2011).

Stephens, K. (2000). A Critical Discussion of the 'New Literacy Studies'. British Journal of Educational Studies. 48 (1), 10- 23.

Street, B. (1984). Literacy in Theory and Practice. Cambridge: Cambridge University Press.

Street, B. (1998). 'New Literacies in Theory and Practice: What are the implications for language in education?'. Linguistics and Education. 10 (1), 1-24.

Street, B. (2000). 'Literacy events and Literacy Practices'. In M. Martin-Jones and K. Jones (eds), Multilingual Literacies, Reading and writing different worlds. Amsterdam,

Philadelphia: John Benjamins Publishing Company

Street, B. (2003) What is New in New Literacy Literacies? Critical Approaches to Literacy. Theory and Practice. Current Issues in Comparative Education, 5(2), 1-14.

Street, B. V. and Street, J. (1995). 'The Schooling of Literacy'. In P. Murphy, M. Selinger, J. Bourne and M. Briggs (eds), Subject Learning in the Primary Curriculum. London: Routledge.

Tharp, R. and Gallimore, R. (1989). Rousing Minds to Life: Teaching, Learning and Schooling in Social Context. Cambridge, England: Cambridge University Press. Valdez, G. (1996). Con Respeto: Bridging the Distances between Culturally Diverse Families and Schools: An Ethnographic Portrait. Teachers College Press, New York. Volk, D. (1997). Questions in Lessons: Activity settings in the homes and the school of two Puerto Rican kindergartners. Anthropology and Education Quarterly. 28 (1), 22-49.

Volk, D.\& De Acosta, M. (2001). "Many differing ladders, many different ways to climb...": Literacy events in the bilingual classroom, homes and community of three Puerto Rican kindergartners. Journal of Early Childhood Literacy. 1, 193-224.

Vygotsky, L. S. (1987). The Collected Works of L. S. Vygotsky, Vol.1: Problems of General Psychology, Including the Volume Thinking and Speech. Reiber, R. \& Carton, A. (eds). New York: Plenum

Yin, R. K. (1994). Case Study Research: Design and Methods (2nd Edition). London: Sage Publications. 